\title{
Database of Forest Understory Vegetation, British Columbia - vascular plants and bryophytes in old-growth and clear-cut forests, Vancouver Island
}

\author{
Judith D. Toms
}

\begin{abstract}
Understory plant communities were surveyed at two sites on Vancouver Island, British Columbia, Canada, from $100 \mathrm{~m}$ into 5-15 year-old clearcuts to $200 \mathrm{~m}$ into old-growth stands, along three transects placed perpendicular to the forest edge. Presence/absence of bryophytes, herbaceous and woody species was measured in 10x10 m plots, scattered along the length of each transect $(10,30,50,75$ and $100 \mathrm{~m}$ in the clearcut, and 10,30, 50, 75, 100 and $200 \mathrm{~m}$ in the old-growth stand). While the data was collected to estimate edge effects in the understory plant community, other uses of the data are encouraged. This report describes the available content in the Database of Forest Understory Vegetation, British Columbia (GIVD ID NA-CA-001).
\end{abstract}

Keywords: ecological threshold; presence-absence.

GIVD Database ID: NA-CA-001

Last update: $2012-07-08$

\section{Database of Forest Understory Vegetation, British Columbia}

Scope: Presence/absence data of understory plants (bryophytes, herbaceous and woody plants) in $10 \times 10 \mathrm{~m}$ plots. Plots were located along a transect placed perpendicularly to the boundary between 5-15 year-old clearcut and old-growth forests, at 10,30,50,75 and $100 \mathrm{~m}$ into the clearcut, and 10, 30, 50, 75, 100 and $200 \mathrm{~m}$ into the old-growth stand. Three transects were measured at each of two sites.

Status: finished

Period: 1996-1996

Database manager(s): Judith D. Toms (judithtoms@gmail.com)

Owner: Judith D. Toms

Web address: http://esapubs.org/Archive/ecol/E084/047/suppl-1.htm

Availability: free online

Online upload: no

Online search: no

Database format(s): CSV file

Export format(s): CSV file

Publication: Toms, J.D. 1997. Edge Effects in Understory Vegetation Due to Clearcutting of Old-growth Western Hemlock Forests. Honours Thesis, University of Victoria, Victoria, B.C., Canada.

Plot type(s): normal plots

Non-overlapping plots: 72

Plot-size range: $100-100 \mathrm{~m}^{2}$

Total plot observations: 72

Estimate of existing plots: 72

Number of sources: 2

Completeness: $100 \%$

Valid taxa: $[N A]$

Countries: CA: $100.0 \%$

Forest: [NA] — Non-forest: [NA]

Guilds: all vascular plants: $100 \%$; bryophytes (terricolous or aquatic): $100 \%$

Environmental data: [NA]

Performance measure(s): presence/absence only: $100 \%$

Geographic localisation: political units or only on a coarser scale (>10 km): $100 \%$

Sampling periods: $1990-1999: 100.0 \%$

Information as of 2012-07-12; further details and future updates available from http://www.givd.info/ID/NA-CA-001

Judith D. Toms (JudithToms@gmail.com)

Eco-Logic Consulting, 3014 Craigowan Rd, Victoria, B.C. V9B 1M8, CANADA 